\title{
Resettling Displaced Residents from Regularised Informal Settlements in Dar-es-Salaam, Tanzania: Challenges Faced by House Owners
}

\author{
D. L. Magembe-Mushi, J. M. Lupala \\ Ardhi University, Dar es Salaam, Tanzania \\ Email: dimushi2000@yahoo.com
}

Received 26 March 2015; accepted 17 May 2015; published 21 May 2015

Copyright (C) 2015 by authors and Scientific Research Publishing Inc.

This work is licensed under the Creative Commons Attribution International License (CC BY).

http://creativecommons.org/licenses/by/4.0/

(c) (i) Open Access

\section{Abstract}

Regularisation is a process that attempts to restructure informal and unauthorised settlements in terms of physical, legal, official and administrative set ups of land management as well as improving the living condition of its dwellers. In Dar-es-Salaam city about, 80 per cent of its residents live in informal settlements. These settlements lack the basic services of water supply, access roads, waste water management and storm water drainage systems. Regularisation has been practiced in order to provide these basic services. This paper focuses on physical regularisation which was implemented through Community Infrastructure Upgrading Project (CIUP) within sixteen settlements in Dar-es-Salaam City. Through explorative research using case study strategy, displaced residents were traced. For those who were found an in-depth interview was conducted and narrations of their experience before during and after displacement and resettlement were obtained. The paper analyses the process of displacement and resettlement caused by regularisation through the country's policy and legal frameworks. It also used the justice and collaborative theories in reflecting the processes in the affected settlements. Through narrations of individual displaced residents and reflections from theories and legal frameworks, a number of challenges were identified and discussed.

\section{Keywords}

Regularisation, Upgrading, Displaced Residents, Resettlement, Displacement 


\section{Introduction}

Regularization has been defined as a planned process of physical restructuring of informal and unauthorized settlements into legal, official and administrative structures of land management. The process consists of two main approaches: judicial/tenure regularization and physical regularization, also known as upgrading (Mertins, 1998; Lamba, 2005).

Regularisation as a new paradigm in addressing issues in informal settlements has become an accepted way of solving problems associated with unplanned settlements in most African, Asian and Latin American cities. International organisations, such as United Nations Development Program (UNDP), UN-Habitat and the World Bank, had substantiated that. Since 1960s, cities in developing countries have faced an unprecedented rate of urbanisation and increasing poverty which had resulted into uncontrolled proliferation of slums within unplanned and under-serviced neighbourhoods (Durand-Lasserve, 2006). These slums are occupied by dwelling units without any legal recognition or rights to land. They lack the most basic social amenities, such as clean water supply, sanitation, waste collection and health facilities. Consequently, these slums are exposed to diseases and natural disasters (World Bank, 2001).

Although the views of many governments in developing countries over informal settlements were largely negative, in the past three decades these views have changed quite dramatically. Informal settlements are no longer seen by public authorities as a transitory phenomenon, rather as permanent and lasting fact of life. Integration of informal settlements has become a step towards a new form of managing urban development (World Bank, 2001). This is why regularisation is considered as a workable strategy of improving the living condition of such settlements and incorporating them into urban development strategies. Regularisation has been also viewed as a strategy to achieve inclusivity of marginalised poor communities within city social-economic development (ibid).

Physical regularisation which is the focus of this paper, involves the spatial reorganisation of informal settlements. The process allows for the material creation and/or improvement of physical infrastructure, including dwelling structures; basic urban services such as access roads, water, sanitation facilities; social amenities like schools and health facilities. In this approach, it is difficult to avoid some population displacement in any city when the government seeks to improve provision of infrastructure in settlements (Patel, 2002). The process usually starts with the acquisition of land which will be used for infrastructure provision. In informal settlements the availability of unoccupied pieces of land is very rare. In order for the community to be provided with basic infrastructure and other social amenities, a number of houses or part of these houses have to be demolished to pave way for such an implementation. Since the whole process of regularization has to be done in a participatory approach, it is assumed that the community in collaboration with the government or its agent will find alternative sites for resettlement of the affected residents. Various researches have advocated relocation to be within or very close to the settlement in order to make affected residents benefit from the regularisation process. This is attributed to the aim of upgrading which is to improve health and secure living environment for the residents of the settlement with minimal displacement (World Bank, 2001).

\section{Regularisation in Tanzania}

Tanzania is one of the countries in the Sub-Saharan region with the highest proportion of its urban residents living in informal or unplanned settlements. Between 50 percent and 80 percent of its urban population live in such settlements. Dar-es-Salaam in particular, over 70 percent of the estimated 3 million inhabitants lives in unplanned settlements (URT, 2004). Informal housing comprises more than 50 percent of the existing urban housing stock (Kombe, 2005).

Efforts in dealing with informal settlements started early after independence in 1960s following rapid influx of rural population into urban centres. In dealing with such a situation of informal settlements the government adopted the strategy of slum clearance. The idea of this strategy was to clear away the city squatters, who were considered as "eyesore" to the cityscape (Ndezi, 2009). Due to rapid population growth, the government failed to provide housing services to cope up with that situation. With increasing poverty in the rural and urban areas, the administrative and financial capability of the state to cope with effective demand for housing has been diminishing. Thus the potential to provide subsidised rental housing and serviced plots or expand opportunities for employment and income generation commensurate with population growth has declined (Kombe, 2005).

It is common that the majority of the migrants seek accommodation in informal settlements. From 1972; the 
government adopted the upgrading approach to take advantage of the housing stock developed by people. In that case, the Government of Tanzania adopted a second approach known as Site and Services and Squatter Upgrading program. This strategy stipulated the recognition of squatter settlements as part and parcel of urban fabrics. The essence was to legalise landholding by giving titles, thus providing a minimum level of social and economic infrastructure and services in squatter settlements (URT, 2000). While the program had positive impact on housing delivery and urban improvements where it was implemented, it as well displaced residents from the upgraded settlements. These residents were resettled in the provided new sites which were planned and serviced. However, many of the planned plots ended up in the hands of high-income people while the targeted beneficiaries were supposed to be low-income earners (Kironde, 1992).

From the 1990s, regularisation approach got prominence essentially because it incorporated tenure improvement to the residents. The period between 1986 and early 1990s observed a stall in informal settlements development. Due to lack of maintenance, most of the infrastructure provided under the squatter upgrading and sites and services programme deteriorated beyond repair. New informal settlements emerged with little or no intervention from the government. As this trend intensified the demand for services and public utilities increased as well. Many residents from these settlements pursued their needs from community based initiated upgrading projects. It was from these community based initiatives the government adopted community infrastructure program (CIP) in 1993, and extended further under the Community Infrastructure Upgrading Programme (CIUP) in 2002. In these programmes more than 30 informal settlements were earmarked for upgrading in Dar-es-Salaam with emphasis on community participation in the upgrading process.

Regularisation as an approach in upgrading also came into effect following the enactment of the Land Act No 4 and 5 of 1999. The Act provides for the adoption of regularisation of informal settlements with emphasis of titling of properties and plots. About five informal settlements in Tanzania have implemented such a process and two are in plans to do as such.

\section{Conceptualisation and Theoretical Review}

Displacement as a concept of this paper may be either physical or economic. Physical displacement is the actual relocation of people resulting in a loss of shelter, productive assets or access to productive assets such as land, water, livestock, and forests (IFC, 2002). Displacement requires the affected person(s) to move to another location that is resettling. During this process it is argued that economic displacement results from an action that interrupts or eliminates people's access to productive assets without physically relocating the people themselves. The process of physical displacement (Figure 1) is associated with the following components which are likely to be faced by any displaced population in development projects (Cernea, 1996; Downing, 2002).

According to the literature review on development-induced displacement undertaken, the components are conceptually described as follows:

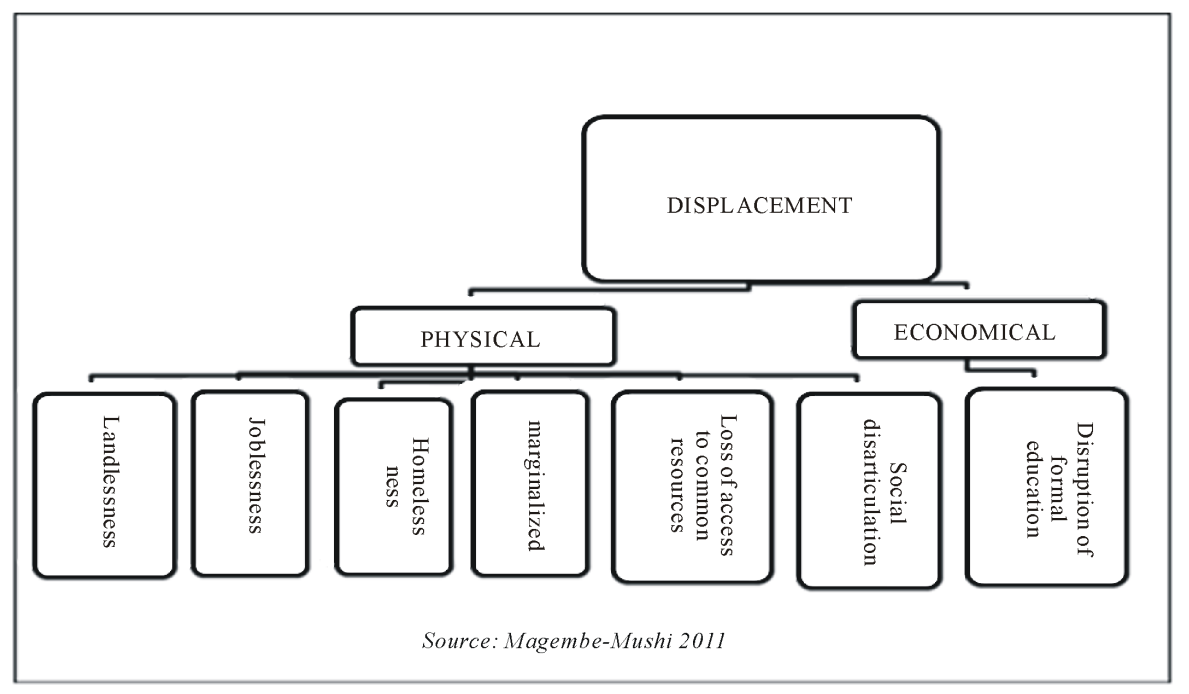

Figure 1. Conceptual framework-components of displacement. 


\subsection{Landlessness}

This component of landlessness has been explained as:

... expropriation of land. It removes the main foundation upon which people's productive systems, commercial activities, and livelihoods are constructed on. This is the principal form of de-capitalization and pauperization of displaced people, as they lose both natural and man-made capital (Cernea, 1996: 18).

Land to the urban poor like those found in informal settlements can be considered as the main resource which helps them deal with livelihood strategies. This resource can facilitate the poor to have a shelter to live in, economic activities to give them income and social networks to depend on.

\subsection{Joblessness}

Joblessness was defined as losing employment or any other source of income generating activity. Cernea (1996: 19) again explained it as:

The risk of losing wage employment is very high both in urban and rural displacements for those employed in enterprises, services, or agriculture.

Yet, creating new jobs is difficult and requires substantial investment unless fair and rightful allocation of resources is practiced for both displaced and remaining residents. "Unemployment or underemployment among displaced population often endures long after physical relocation has been completed” (Cernea, 1996: 19).

\subsection{Homelessness}

When discussing mining-induced displacement and resettlement, Downing (2002: 10) explains that the pattern of new poverty persists in homelessness as another component of displacement risk. He defined homelessness as the "loss of house-plots, dwellings and shelter". Cernea further explains that

Loss of shelter tends to be only temporary for many displaced people; but, for some, homelessness or a worsening in their housing standards remains a lingering condition. In a broader cultural sense the loss of a family's individual home and the loss of a group's cultural space tend to result into separation and status-deprivation (Cernea, 1996: 20).

\subsection{Marginalisation}

According to Fernandes (2000), marginalisation is among the components of displacement and resettlement risks and its characteristics are multiple due to the fact that the cultural status of displaced residents is reduced when they shift to new resettlement areas. In these resettled areas displaced people are regarded as "strangers" and deprived of opportunities and entitlements. This situation is assumed to last for certain period of time, but still can result into both social and economic marginalisation and its consequences are typically not considered in resettlement and compensation programs.

\subsection{Loss of Access to Common Resources}

Loss of access to common resources not only happen in rural areas whereby it is assumed that most of the livelihood assets are commonly owned, but also in cities where important assets are commonly provided and accessed. Moving away from such facilities, can create disturbance or change of a lifestyle of the urban poor and result into unfair and unrightfully allocation of resources. For poor people, particularly for the landless and asset less, loss of access to the common property that are available in or closer to previous community will affect income and livelihood levels. Such common resources include water sources, burial grounds, market/trading place, community halls. These resources can be within the informal settlement or can be accessed in a neighbouring community. Loss of access to such resources results in significant deterioration in chances to practice personal skills (Cernea, 1996; Rawls, 1999).

\subsection{Social Disarticulation}

Cernea (1996) explains social disarticulation as another component of displacement and resettlement risk as it is 
assumed to tear apart the existing social structure. It disperses and fragments communities, dismantles patterns of social organisation and interpersonal ties; kinship groups become scattered. Life-sustaining informal networks of reciprocal help, local voluntary associations, and self-organised mutual service are disrupted. Cernea again describes the loss of social capital as the social capital lost through social disarticulation is typically unperceived and uncompensated by the programs causing it, and such a loss has long-term consequences (Cernea, 1996: 25).

\subsection{Disruption of Formal Educational Activities}

According to Downing, displacement and resettlement processes often cause a significant interruption in the functioning of schools and in child access to education during the period of relocation and for longer periods of time after relocation. Studies done by Downing on mining-induced resettlement show that a number of relocated students often never return to school and instead join the labour force at an early age (Downing, 2002: 11). This can be due to factors such as unavailability of school in the resettled area, the increase in travelling distances to the previous school. Change of lifestyle for the displaced families as a result of loss of livelihood strategies such as employment or business activities can make them not able to afford school fees, or any other costs associated with attending school.

\section{Theoretical Review}

The above seven components of the displacement concept were combined with two selected theories and looked at the displaced residents in their settlements. The selected theories are those of Justice Theory by Robert Rawls and Communicative and Collaborative planning theory. The two theories were selected as they both advocate the issue of democracy in order to bring equality in the society. The justice theory provides factors which have to be considered in order to bring democracy in a diverse society. These factors are in the principles of justice as fairness which states on the appropriate distribution of benefits and burdens of social cooperation as well as democracy and participatory development (Rawls, 1999).

Collaborative and Communicative planning theory was advocated by a number of authors such as Patsy Healey, Jorgen Habermas and others. This theory entails planning through debate, arguments, inclusionary discourse and collaborative planning. It believes that if there will be a freedom of speech and rational arguments, equality through democracy and participatory approach can be achieved (Bond, 2011). In the research, the above seven components of displacement were looked at in the settlements which implemented the CIUP. Also reflections towards the reviewed two theories were made in order to analyse the challenges faced by the displaced residents. The two theories provide factors and process to be followed in order to attain equality and democracy in a diverse society.

\section{Methodology}

This paper is part of the licentiate research conducted in February to June, 2011 as part of the PhD programme at Ardhi University in Dar-es-Salaam, Tanzania. The research was conducted within sixteen settlements which were selected for the implementation of CIUP phase I project. Within the sixteen settlements only five settlements-Mnazi Mmoja, Kilimani, Midizini in Manzese Ward; Mnyamani, and Madenge in Buguruni Wardqualified for the research, as these settlements had displaced residents who needed resettlement. The research was explorative whereby the identified displaced residents were traced by using the snow balling method, after which an in-depth interview was conducted with those who were found. In the whole CIUP project implementation, eight houses were completely demolished and displaced its residents. In that case there were eight house owners of which only four were traced and found for detailed interviews purposes (see Table 1 for more details of sample selection). The interviews provided narratives which were developed from the experiences of each individual displaced resident. The fact that this study was more of a qualitative than quantitative, the four house owners that were found, provided adequate information as required by the research questions that were raised at the beginning of the study.

\section{Challenges of Displacement Faced by Displaced Residents}

Through the explorative research approach, the findings obtained from in-depth interviews indicate that all the house owners resettled outside the settlement, ranging from 2 to 28 kilometres away from the previous settle- 
ment. The far most, that is a house owner from Manzese settlement which is an informal settlement within the inner city of Dar-es-Salaam, moved to Makurunge village in Kiluvya Ward about 28 kilometres from Manzese Ward. The second far most were two house owners from Mnyamani settlement in Buguruni Ward which is also an informal settlement within the inner city. The two house owners resettled in Chanika Ward which is 20 and 25 kilometres respectively, away from Mnyamani settlement. The closest of them all was a house owner who moved from Madenge settlement, to Buguruni Kisiwani which is 2 kilometres away from Madenge settlement (Figure 2) (Magembe-Mushi, 2011).

The four displaced house owners had a common reason of resettling outside the settlement. The reason was that they were not able to find alternative plots which they could afford with the money they got for compensation from their former settlements. That was due to the fact that, in informal settlements such as Manzese and Buguruni Wards, it is not possible to find an empty plot. In that case further investments are made by buying existing houses. For the case of Manzese for example, a house occupying a minimum plot of 20 by 40 metres was sold from TZS 10 million to TZS 50 million (equivalent to USD 6900 to 34,500) depending on its location and condition. Therefore, these house owners had no choice than moving to their previous owned plots or farms outside the City's built up areas. The house owner from Buguruni Ward, in Madege settlement, who was able to buy a house within 2 kilometres, was an exceptional case. He was able to do that since that settlement he bought the house was not that much developed and it was mostly inhabited by the native people of Dar-es-Salaam. With such a situation this house owner and his wife faced the problem of marginalisation within his resettlement area due to difference in ethnic groups.

Owing to resettling to their previous plots/farms, the other three house owners avoided some of the issues which were discussed by Cernea, (1996) and others in associated with resettlement outside their settlements. These issues include that of becoming landless and homeless. These house owners were affected with other factors such as joblessness, marginalization, socially disarticulation, family disintegration and loss of access to common resources, as indicated in Table 2.

\subsection{Loss of Access to Common Resources}

As a result of resettling outside their settlements the three house owners lost the opportunity of accessing common

Table 1. CIUP Phase I implemented settlements and potential case study settlements.

\begin{tabular}{|c|c|c|c|}
\hline Municipality & Wards & Sub-wards & Remarks \\
\hline \multirow{4}{*}{ Ilala } & \multirow{3}{*}{ Buguruni } & Mnyamani & Three houses were totally demolished \\
\hline & & Madenge & $\begin{array}{l}\text { One house was totally demolished but the } \\
\text { owners were not found }\end{array}$ \\
\hline & & Malapa & No house was totally demolished \\
\hline & Vingunguti & Mtambani & No house was totally demolished \\
\hline \multirow{5}{*}{ Kinondoni } & \multirow{5}{*}{ Manzese } & Manzese Uzuri & No house was totally demolished \\
\hline & & Kilimani & $\begin{array}{l}\text { One house was totally demolished which } \\
\text { happened to be a church therefore no } \\
\text { displacement }\end{array}$ \\
\hline & & Midizini & One house was totally demolished \\
\hline & & Muungano & No house was totally demolished \\
\hline & & Mnazi Mmoja & One house was totally demolished \\
\hline \multirow{6}{*}{ Temeke } & \multirow{3}{*}{ Chang'ombe } & Chang'ombe A & No house was totally demolished \\
\hline & & Chang'ombe B & No house was totally demolished \\
\hline & & Toroli & No house was totally demolished \\
\hline & \multirow{3}{*}{ Sandali } & Sandali & $\begin{array}{l}\text { One house was totally demolished but the } \\
\text { displaced residents were not found (died) }\end{array}$ \\
\hline & & Mpogo & No house was totally demolished \\
\hline & & Mwembeladu & No house was totally demolished \\
\hline
\end{tabular}

Source: The Government of Tanzania (2004) and modified by the author. 


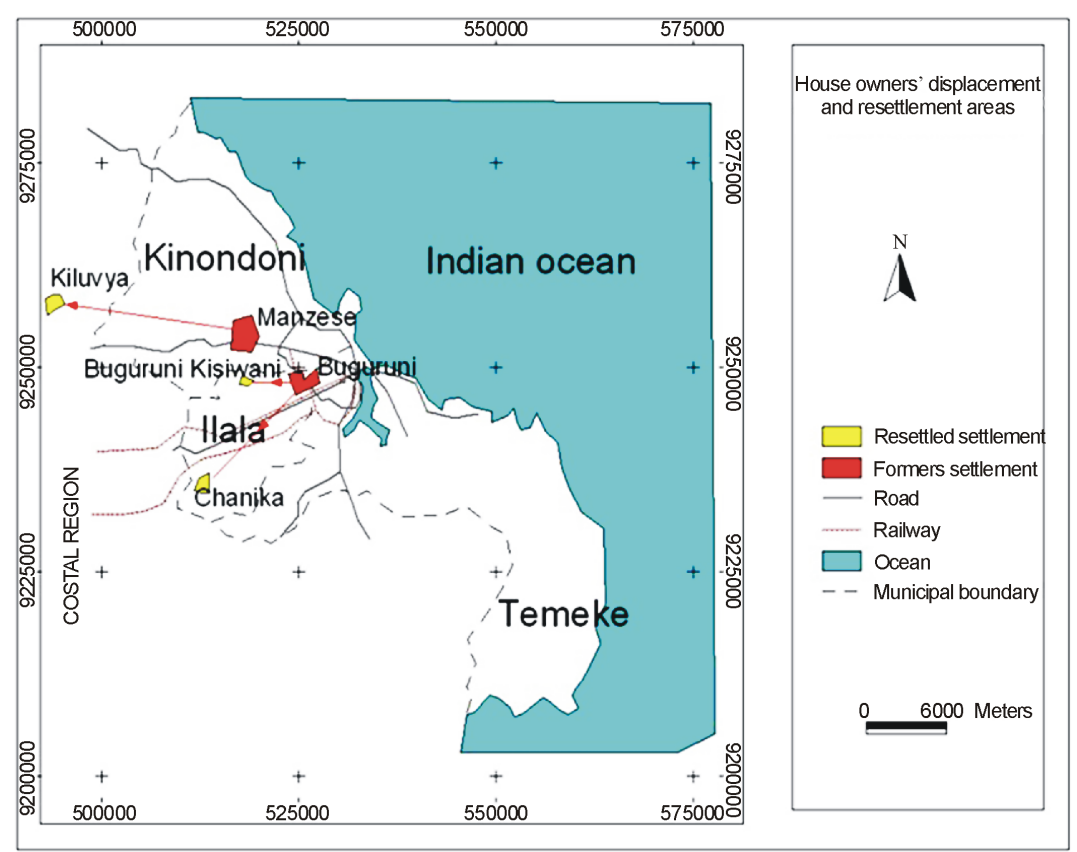

Figure 2. Location of resettlement areas for affected house owners. Source: Magembe-Mushi, 2011: 121.

Table 2. Challenges faced by resettled House Owners.

\begin{tabular}{|c|c|c|c|c|c|}
\hline \multirow{2}{*}{$\mathbf{S} / \mathbf{N}$} & \multirow{2}{*}{ Challenges } & \multicolumn{4}{|c|}{ House owners } \\
\hline & & House owner 1 & House owner 2 & House owner 3 & House owner 4 \\
\hline $\mathrm{i}$ & $\begin{array}{l}\text { Loss of access to } \\
\text { common resources }\end{array}$ & $\begin{array}{l}\qquad \sqrt{ } \\
\text {-accessed in } 8 \text { - } 12 \mathrm{kms} \\
\text { away } \\
\text {-buying water for daily uses }\end{array}$ & $\begin{array}{l}\qquad \sqrt{ } \\
\text {-lack of nearby } \\
\text { primary school } \\
\text {-no public transport }\end{array}$ & $x$ & $\begin{array}{c}\sqrt{ } \\
\text {-no social services }\end{array}$ \\
\hline ii & Social disarticulation & $x$ & $x$ & $x$ & $\begin{array}{c}\sqrt{ } \\
\text { Considered as a stranger }\end{array}$ \\
\hline iii & Marginalized & $\times$ & $\times$ & $x$ & $\begin{array}{l}\sqrt{ } \\
-\end{array}$ \\
\hline iv & Joblessness & $\begin{array}{c}\sqrt{ } \\
\text {-loss of rents from tenants }\end{array}$ & $x$ & $\begin{array}{c}\sqrt{ } \\
\text {-loss of rents from tenants }\end{array}$ & $x$ \\
\hline $\mathrm{V}$ & Family disintegration & $\begin{array}{l}\qquad \sqrt{ } \\
\text {-small house to accommodate } \\
\text { all family members }\end{array}$ & $\begin{array}{l}\qquad \sqrt{ } \\
\text {-unfinished } \\
\text { resettlement house }\end{array}$ & $x$ & $x$ \\
\hline vi & $\begin{array}{l}\text { Disruption of formal } \\
\text { activities }\end{array}$ & $\begin{array}{l}\qquad \sqrt{ } \\
\text { missing school during reset- } \\
\text { tlement period }\end{array}$ & $x$ & $x$ & $\times$ \\
\hline vii & Landlessness & $x$ & $x$ & $x$ & $x$ \\
\hline viii & Homelessness & $x$ & $x$ & $x$ & $x$ \\
\hline
\end{tabular}

Source: Interviews with house owners in Mmazi Mmoja and Midizini in Manzese Wardand Mnyamani and Madege in Buguruni Ward, February-May, 2011. Key: V: Yes; ×: No.

resources which were available in their previous settlements. For example house owner 1, in her previous settlement she was able to access social facilities such as water supply from a common water kiosk, a health centre, a primary school, a police post and bus stop for public transport linked to different parts of Dar-es-Salaam City, 
in 10 to 15 minutes walking distance.

At her new settlement in Kiluvya, this house owner had to go 8 to 12 kilometres away from her home to get access to some of the common resources she used to get within 15 minutes' walk. This owner was complaining that;

It was very difficult even to buy soap for daily cleanliness. In order to get meat and other groceries I have to travel 8 kilometres to a settlement called Kiluvya where I can get such services. When it comes to medical services I and the rest of Makurunge community have to go to Tumbi Hospital in Kibaha which is 12 kilometres from my house.

She added that it has become very expensive to get water supply. Since she gets it through vending trucks from an area known as "Maili Moja" and it costs TZS 20,000 (USD 13.5) per 1000 litres, Tshs 30,000 (USD 20) per 2000 litres and Tshs 45,000 (USD 30) per 3000 litres (Megembe-Mushi, 2011).

Such a situation of inaccessibility to common resources was also experienced by the other two house owners.

\subsection{Social Disarticulation and Marginalisation}

In the regularisation projects in Manzese and Buguruni, social disarticulation and marginalisation was faced by house owner no. 4 from Madenge settlement. This house owner bought a house; he did not go back to his previous plot/farm like the other three. Such a situation made him considered as a "stranger" within that new society as he had no relations with that settlement before buying the house. For those who had farms/plots previously, they were already part of that society though they were not residing there but they were known and considered to be part of the community (Magembe-Mushi, 2011).

This house owner from Madenge complained that;

I and my wife felt out of place in that new settlement. We were fragmented from the community we used to live and help each other in times of need.

Resettlement also disturbed their interpersonal ties with the neighbours. House owner no. 4 recalled in his interview that;

Even though we had no children in my marriage but me and my wife were helped with our neighbours' children as we were part and parcel of that community.

To such a house owner and his wife, resettlement also tore apart their social relations. He explained that, they felt marginalised as they had resettled in a society which is completely new to them, hence they were regarded as strangers and that made him and his wife feel uncomfortable and out of place immediately after resettling in that settlement.

\subsection{Joblessness}

Even though three out of four house owners were retirees resettlement did not cause impact to them in terms of employment, as they were all out of formal employment before resettlement. But somehow the resettlement hindered one of the house owners to continue with her income generating activities. These activities were her source of income after retirement in her previous settlement. This house owner no. 1 explained that;

Although I have a bigger plot/a farm, compared to the plot I owned while at Manzese, due to my old age I am not able to practice farming activities. My economic status had been worsened as I have no other sources of income. I solely depended on my grandchildren to support me with my daily expenses.

She added that she could have engaged herself with petty trading at her home, but she had no capital for such an activity. If she could have had capital she could start selling soft drinks to primary school children as the school is located only 2 kilometres from her resettlement house. The funds she had was used for resettlement process.

Joblessness was also felt in terms of loosing income which was obtained from renting rooms to tenants. For example, house owner no.1 had three tenants in her demolished house who paid her TZS 8000/= equivalent to USD 5.5 (by 2011). That means she was getting at least 24,000/= (USD 17) per month.

This challenge was also suffered by house owner no. 3 . This house owner only suffered from being jobless as 
the demolished house had four tenants each paying TZS 4000/= per month (USD 2.8). These rents were used as a source of income to her family. This house owner did not suffer the rest of the challenges of displacement and resettlement as she inherited the house from her parents who were living in Mnyamani settlement. She with other members of her family was living in Chanika even before resettlement; in her parents' farm which was later used to construct the resettlement house.

\subsection{Family Disintegration}

Family disintegration is also one of the challenges faced when displaced households get resettled. This situation was faced by two house owners. These house owners suffered family disintegration after resettlement due to two situations. The first situation was when the house owner no. 1 from Manzese was immediately resettled to Makurunge in her small temporary house, in which the owner referred to as a hut. The hut was too small to accommodate all the seven people of her household. These people included the house owner, her late mother, her grandson and his wife and her daughter in law, who is a window of her late son and her two grandchildren. That means seven people in two roomed house. Due to resettlement challenges the grandson and his wife, and the daughter in law could not tolerate the life in Makurunge with limited access to social service. They both relocated to Kiluvya which is about 8 kilometres from Makurunge. This house owner was left with her two grandchildren since her mother passed away a year after they had resettled (Magembe-Mushi, 2011).

The second house owner experienced family disintegration in a different way. This house owner no. 2 had to leave his family, a wife and seven children and three grandchildren in their other house in Mnyamani. The house owner did that since he was yet to finish his resettlement house in his farm in Chanika. In that case this house owner had to live alone in Chanika without his family.

The family disintegration faced by these two house owners has result into split of households. Even though these household changes could be considered as part and parcel of urbanisation and modernisation but they somehow increased expenses within the urban life style of the poor.

\section{Reflections from the Theoretical Reviews and Policy Frameworks}

In implementing its programs the World Bank formulated policy framework to guide their implementation. For instance in implementing Regional Communications Infrastructure Program (RCIP) which the CIUP fall under it, the World Bank realized that there would be land acquisition, loss of access to economic assets and resources and ultimately compensation and resettlement of people. The World Bank resettlement framework made provisions in case this situation is inevitable so as to make sure both the displaced and the remaining residents benefit from the project (ERM, 2007).

The principles of the general framework which was also reflected in the Community Infrastructure Upgrading Program's (CIUP) Resettlement Action Plan (RAP) include the following. First, involuntary resettlement should be avoided or minimized, by exploring all viable alternatives. If that is not possible then the resettlement and compensation should be conceived and executed in a sustainable way and give the displaced people opportunities to share the project benefits. Second, the displaced and compensated people have to be meaningfully consulted and participate in planning and implementation of resettlement and compensation programs. Third, the displaced people should be assisted in their efforts to improve their livelihoods and standards of living or at least to restore them in real terms to the situation before displacement. That was considered so as to enable the affected people share the objective of improving their living standard in the same way as those who remain in the project area. This policy framework is in line with elements advocated by the reviewed principles of justice theory and collaborative planning theories as discussed below.

\subsection{Sharing of Benefits}

The first principle of Rawls' Justice Theory advocates on appropriate distribution of benefits as well as burdens within a society (Rawls, 1999). The Resettlement Policy Framework (RPF) made provisions in achieving such a distribution. In the framework, the affected residents such as house owners were supposed to be compensated with the loss of their properties. Such provisions were not fully adhered to as it was complained by the house owners from CIUP affected residents. These house owners complained that though they got compensated but the compensation was very low to the extent that they were unable to attain the level of living conditions, in terms 
of housing as they had before displacement.

\subsection{Democracy and Participatory Consideration}

As it is in Communicative and Collaborative Planning theory, the Resettlement Policy Framework urged for a meaningful and democratic participation of the community especially the affected ones (Bond, 2011). That was so emphasised in order to reduce the hardship which will be caused by the displacement and resettlement process. In such a situation participation which was required or urged was that which would influence the decisions and outcomes of the project. That is why the resettlement and other policies and frameworks emphasise in it so as to reduce the impacts of affected residents. The resettlement policy framework stipulated the formulation of the Community Planning Teams (CPT) with gender and areas representations. This was a way of influencing the project through participatory approach and in a democratic manner. The CPTs had a responsibility of making sure that the displaced residents were meaningfully consulted and participate so that they could make rational arguments in order to be able to benefit from the project. However, it was realized that the CPT was not given enough power to practice its duties and obligations and failed to exercise its power as an organ responsible to ensure that equal benefits and democratic considerations were adhered to. Nevertheless, the affected house owners consented to have their houses demolished and given compensation equivalent to the values of the houses.

\subsection{Liberty}

One of the concepts in the principles of Justice Theory is liberty whereby freedom or right to choose is advocated. It refers to the power to do as one pleases that is, the power of choice (Rawls, 1999). The research findings give an indication that all the house owners were at liberty to choose to let go their properties with the agreed amount of compensation. The narratives indicate that the house owners were consulted on the total demolition of their houses and they were willing to allow that. It was indicated that, some of the house owners thought the demolition was a good thing to them. Since their houses were in poor conditions and these house owners had no other means of renovating them. The problem came on the level of information that the house owners were provided with before being at liberty to let go their properties. It is advocated by the communicative and collaborative planning theory that the most appropriate and democratic means of decision making in planning should be based on the premises of debate between all relevant stakeholders oriented towards agreement (Bond, 2011). Even though it was explained that the house owners were informed about the compensation rates and those who were not pleased with the amount were free to express their concerns. The dissatisfaction was based on not knowing what exactly the land owners were going to lose. The loss was on the property; location and the increased land value as well as improved social services and facilities. All these were not considered in the compensation.

\subsection{The Difference}

According to Rawls theory of Justice, the focus of this concept of difference is concerned with the achievement of the greatest benefits to the least advantaged groups within a diverse society. The second principle of justice considered a proper act when person's reactions to gain doesn't affect others, since the principle for an individual is to advance as much as possible his own welfare and the principle for society is to advance as far as possible the welfare of the group (Rawls, 1999). Likewise in the RPF it was stipulated that resettlement and compensation should be conceived and executed in a sustainable way in order to enable the displaced people share the projects benefits (ERM, 2004).

\section{Conclusion}

The findings from Manzese and Buguruni Wards give an indication on how the affected few have been deprived democracy and equity when it comes to enjoying the fruits of development. As according to the reviewed theories, welfare of the affected group of displaced residents was supposed to be shared or considered by the whole community. But such was not the case in Manzese and Buguruni society. Those societies were not facilitated or rather prepared to consider such a notion of sharing benefits and helping each other to reduce the burden of the loss with the disadvantaged ones. The disadvantaged group, in this case the displaced house owners after re- 
ceiving their compensations were left to deal with displacement and resettlement processes. That being the case, they faced difficulties in resettling as discussed in this paper. That can be the result of lack of enough democracy and participatory approach whereby the whole community were not unified. Therefore each group, the benefited and the affected ones considered one another benefiting more from the project. This situation made the displaced residents faced a number of challenges for the benefit of the remaining residents whose living conditions were improved and their properties values increased.

\section{References}

Bond, S. (2011). Negotiating a Democratic Ethos': Moving Beyond the Agonistic-Communicative Divide. Planning Theory, 10, 161-186. http://dx.doi.org/10.1177/1473095210383081

Cernea, M. M. (1996). Understanding and Preventing Impoverishment from Displacement: Reflections on the State of Knowledge. In: C. McDowell (Ed.), Understanding Impoverishment: The Consequences of Development Induced Displacement. Oxford: Berghahn Books.

Downing T. E. (2002). Avoiding New Poverty: Mining-Induced Displacement and Resettlement. MMSD No 58. IIED and WBCSD.

Durand-Lasserve, A. (2006). Informal Settlements and the Millennium Development Goals: Global Policy Debates on Property Ownership and Security of Tenure. Treating People and Communities as Assets. Global Urban Development, $2,5$.

Environmental Resource Management (2007). Resettlement Policy Framework. Regional Communications Infrastructure Program (RCIP) Phase 1. Washington DC, 20.

Kironde, J. L. M. (1992). Creations in Dar-es-Salaam and Extensions in Nairobi. The Defiance of Inappropriate Planning Standards. Cities, 9, 220-231. http://dx.doi.org/10.1016/0264-2751(92)90017-y

Kombe, W. (2005). Land Use Dynamics in Peri-Urban Areas and Their Implications on the Urban Growth and Form: The Case of Dar es Salaam, Tanzania. Habitat International, 29, 113-135.

Lamba A. (2005). Land Tenure Management Systems in Informal Settlements: A Case Study in Nairobi. MSc. Thesis Submitted to the International Institute for Geo-Information Science and Earth Observations (ITC). Enschede, the Netherlands, 78.

Magembe-Mushi, D. L. (2011). Resettling Displaced Residents from Regularised Settlements in Dar-es-salaam City, Tanzania: The Case of Community Infrastructure Upgrading Program (CIUP). Licentiate Thesis in Infrastructure; Planning and Plan Implementation. Royal Institute of Technology, Stockholm, 117.

Mertins, G., Popp, J., \& Wehrmann, B. (1998). Land Tenure and Land Regularization in Informal Urban Settlements in Developing Countries. GTZ. Marburg.

Ndezi, T. (2009). The Limit of Community Initiatives in Addressing Resettlement in Kurasini Ward, Tanzania. Environment and Urbanization, 21, 77-88. http://dx.doi.org/10.1177/0956247809103005

Patel, S., d’Cruz, C., \& Burra, S. (2002). Beyond Evictions in a Global City: People-Managed Resettlement in Mumbai. Environment and Urbanization, 14, 159-172. http://dx.doi.org/10.1177/095624780201400113

Rawls, R. (1999). A Theory of Justice. Revised Edition, Cambridge, MA: Harvard University Press.

The Government of Tanzania (2004). Resettlement Action Plan (RAP). Community Infrastructure Upgrading Program in Dar es Salaam under LGSP. UCLAS and DHV Consultants.

The International Finance Corporation (IFC) (2002). A Handbook for Preparing Resettlement Action Plan. 2121 Pennsylvania Avenue, NW Washington, DC, 20433 USA. www.ifc.org

The World Bank Group (2001). Upgrading Urban Communities—A Resource Framework 1999-2001. http://web.mit.edu/urban upgrading/upgrading/index.html

United Republic of Tanzania (2000). National Human Settlements Development Policy. Dar-es-Salaam: Ministry of Lands, \& Human Settlements Development.

United Republic of Tanzania (2004). Dar Es Salaam City Profile. Document Prepared by Dar-es-Salaam City Council. 